\title{
Infected and/or Affected by HIVIAIDS Children in the Classroom: Teachers Role
}

\author{
Maphetla M Machaba \\ Department of Early Childhood development, University of South Africa \\ P.O Box 392 Muckleneuk 0003 \\ machabmm@unisa.ac.za
}

\section{Doi:10.5901/mjss.2014.v5n20p1493}

\begin{abstract}
HIVIAIDS arrived on the world scene without warning. A few decades ago it was unknown - lurking somewhere, waiting for the right moment to ambush the human race. Today HIVIAIDS covers Africa in dark clouds of fear, uncertainty and suffering. The virus has destroyed innocent hopes, desires and plans of countless numbers of people whose lives have been cut short by an unseen enemy. Those of us who live in Africa, it is a human catastrophe from which no single one of us in the region will be exempt, because HIVIAIDS affects us all. This truism about the HIVIAIDS pandemic will become ever more evident and obvious as each month and year passes. It is estimated that by 2015, the year in which HIV/AIDS is expected to reach its peak, between $9-12 \%$ of the population will be HIVIAIDS orphans. This indicates that between 3.6 and 4.8 million children under the age of 15 will be without parents or guardians. "A learner who is infected and/or affected by HIV/AIDS in any way will have to cope with the repercussions. If such a learner is still further traumatised by, e.g. discrimination or neglect of any kind in the school situation, the problem will be exacerbated considerably. All learners have a right to lead a normal life, to have quality of life and to reach their potential. It is important for all teachers to realise this and all teachers have a responsibility to equip themselves with the necessary skills to care for and support these learners in the most effective way possible".
\end{abstract}

Keywords: HIVIAIDS, infected children, affected children

\section{Introduction}

According to Hamilton (2002:19) in an article in the Fairlady magazine more or less a million South Africans are currently HIV-infected. This number would double in South Africa in the next ten years if serious behavior change does not occur that could significantly reduce the course of the epidemic. Illness affects mostly people between the age of 15 and 20 . In Africa, six times more girls are infected than boys. The South African Department of Health, states that in this country, the highest infection rate of HIVIAIDS is among girls aged 13 to 19. The United Nations says that half of the boys now aged 15 in South Africa will die from this disease. The Medical Research Council studies (MRC) argues that children in South Africa tend to begin having sex at age 12 (other studies place this at between 13 and 15)

Although HIVIAIDS is (as yet) an incurable disease, and nothing can be done about the prognosis of the disease at this stage, the quality of life of the HIVIAIDS infected learner can be improved. As HIVIAIDS is such a dangerous, contagious and deadly disease, sufferers tend to hide their status. Stigma and secrecy surround HIVIAIDS, having tremendous emotional impact on the infected person. More and more children are affected by HIVIAIDS either because they themselves have this disease or a family member or friend suffers from HIVIAIDS. "The statistical reality of HIVIAIDS in South Africa is that at the end of 1999, 420000 people were living with HIVIAIDS. Of this number, 95000 were children between 0 - 15 years" (Louw, Edwards \& Orr, 2001:3).

\section{Literature Review}

The research aims to establish teacher's role in meeting the needs of HIVIAIDS learners in the classroom. It also aims to establish how teachers support the Infected and/or affected by HIVIAIDS children in the classroom

As more and more learners are affected and infected by AIDS, teachers need to equip themselves with the necessary skills to be able to support these learners and to meet their different needs. In the next chapter, a profile of the learner with HIVIAIDS, the transmission of the virus, the impact of the illness and the needs and the stigma surrounding HIVIAIDS will be discussed. Teachers therefore have an additional responsibility towards learners with HIVIAIDS. They need to know how to deal with such learners in the classrooms and how to meet their needs. Other learners too need to know how to interact with learners that are infected. These preceding arguments lead to the question: What is the role of 
the teachers in meeting the needs of the HIVIAIDS affected learner?

Whiteside (1998:1-3) argues that nearly 15 years after the HIV virus was identified as the virus that causes AIDS, the HIVIAIDS epidemic has spread to virtually all corners of the developing world, and this while the disease remains fatal, and available treatment is inaccessible for the vast majority of infected people.

For education, this problem has critical implications. According to Smart et al. (2001:94) the HIVIAIDS and Human Development report indicates the following points about the impact of HIVAIDS on education: "In 1998, the education system enrolled 12300 learners in primary and secondary education and employed 370000 teachers. This, together with the management and support staff, cost the taxpayer R38 billion. Furthermore, it also pointed out that in other African countries, it has been discovered that number are infected with HIV. In South Africa, a recent, informal, speculative study estimated that at least then teachers die of HIVIAIDS per week over a ten-month period.

\section{The Impact of HIVIAIDS on Learners}

Although HIVIAIDS is a physical illness, its consequences have an effect on society and more specifically on all the dimensions of the sufferer, such as socially, economically, and emotionally. The economic impact on society will now be discussed.

\section{The Economic Impact of HIVIAIDS on Society}

The economic impact of HIVIAIDS is greater than that of other diseases for several reasons: HIVIAIDS hits poor households dramatically. The financial impact that this illness has on households is as much as $30 \%$ greater than from other illness. HIVIAIDS affects the earning capacity of the household at the same time as it is experiencing extra cost in terms of medical care. In many instances there is significant expenditure in search of a "cure". And for those who can afford anti-retroviral (ART) and/other medication, the financial implications can become burdensome. HIVIAIDS often results in disability. Levels of poverty determine health status, diet and ability to treat opportunistic infections.

This disease strikes adults between 25 - 45, some become ill and die in the years when they are potentially optimally economically active. The death of an adult often means the loss of a provider, career and nurturer. Insurance and medical benefits may be lost and funeral costs are an additional strain. These and other expenses can result in the sale of assets (house) forcing children to leave school and perhaps being forced to do lowly paid work to make ends meet. They may also turn to crime or sex work, which results in further social disintegration. The impact in the work place includes a high level of absenteeism, loss of labour, loss of skilled and trained personnel, rising cost of employee benefits, reduced work performance and lower productivity. UNAIDS (2001:14) claims that in South Africa, a study revealed that $26 \%$ of all workers at a sugar mill were living with HIVIAIDS. HIV-positive workers retiring for reasons of ill health in 1990 visited the clinic over 20 times before retiring. Lost productivity associated with this level of absenteeism, clinic and hospital costs, and the training and pay for new workers to replace those who were sick cost the company exorbitant amounts.

The impact on markets includes growth in certain area such as money lending, funeral services and health care, and a decline in other areas such as consumables, especially those bought on credit (Smart, Dennil, \& Pleaner, 2001:93). Whiteside and Sunter (2000:82-91) suggest that the mechanisms through which the epidemic may affect economies are:

- People spending their savings on medication and special food;

- People will begin cashing in insurance policies;

- People selling capital items - the sale of cattle and farms is already known to occur in rural areas.

\section{Economic Impact of HIVIAIDS on Learners}

The economic implications for learners are that they drop out of school early because of financial problems due to parents who are unable to work. Loss of income emanating from unemployment of the sick parent reduces the capacity of the household to support children in schools and may mean reduced ability to pay school fees, purchase uniforms, textbooks, transport costs to school and other school-related dues. The older children may have to leave school and work at home and in paid employment to support the family. When the parents die, the question arises with regard to the redistribution of household assets. This could lead to the fact that the children could be prevented from inheriting from their parents and they could also lose the house they were living in (Hoffman, 1996:136). 


\section{Cognitive Impact of HIVIAIDS on Learners}

Loss of income emanating from unemployment of the sick parent reduces the capacity of the household to support children in schools and may mean reduced ability to pay school fees, purchase uniforms, textbooks, pay transport costs to school and other school-related dues. This leads to the continuous absence from school by children from poor communities who are exposed to diseases such as malaria, bilharzia and cholera, which when combined with poor nutrition, reduces the resistance of their immune system (Hubley, 1995:75-76).

\section{Social Impact of HIVIAIDS on Learners}

Because of the stigmatization that is surrounding HIVIAIDS, families tend to hide the status of an infected family member, thereby denying support that they possibly can get. According to Whiteside (1998:15) the social impact of HIVIAIDS often causes families and communities to be paralysed, a response that is linked to the fear of the unknown new situation in communities where traditional coping patterns give no easy answer to the problem.

The combined social impact of HIVIAIDS such as the care for terminally ill family members and the increasing number of orphans to look after has put the extended family's safety net under great stress. Not only are the grandparents in most of the cases responsible for the care of these orphans, but they are also ostracized from a support system due to the stigmatization of this illness. The family structures and role changes within families will change due to the HIVIAIDS epidemic. Children may be fostered or adopted with the increase of mortality among adults and older people will be under more pressure to care for children as well as the sick adults (Mann, Tarantola, \& Netter, 1992:220).

Since learners who are infected by HIVIAIDS constantly go to hospital or to a doctor, this will disrupt the formation and maintenance of peer relationship and friendship because they are often absent from school. The learner may be absent from school for long periods of time and not be able to participate in the activities of a group, and is denied the opportunity to build friendships within the group (Louw et al, 2001: 17, 18).

A learner who is rejected by peers will feel isolated, lonely and inferior and this could damage his/her self-esteem. Learners with few or no friends run a risk of developing emotional disturbance and relationship disturbance because they feel lonely and isolated. Social and emotional development cannot really be separated because they are intricately interwoven, for example a learner who is rejected by his peer group (social) will be isolated, lonely and inferior (emotional). A learner who has feelings of inferiority (emotional) and has low self-esteem might find it difficult to interact with his peers (social) (Louw et al., 2001:16).

\section{Emotional Impact of HIVIAIDS on Learners}

Children affected by HIVIAIDS do not only experience stigma but they also have to take care of infected parents (Kaufmann, 1995:54). This lead to the changing of roles and the child becomes the caretaker. This implies that the children are forced into an adult role, thereby leaving behind the carefree lifestyle he/she is entitled to as a child. The emotional and psychological implications are numerous. They furthermore suffer multiple bereavement through the loss of fathers, mothers, siblings, aunts and other relatives. These children suffer multiple orphan hood and are also traumatised by separation from their siblings (Webb, 1997:181-184). Most orphans have to deal with the emotions and trauma of looking after a parent who has been sick for a very long time and knowing very well that he is going to die (Mann et al., 1992:225-226).

Strode and Grand (2001:1) claim that these children are forced to leave home due to the death of a parent, they experience loss in familiar surroundings, friends and schooling and can lose hope for the future due to consequent migration. Learners who are affected and infected with HIVIAIDS are often stigmatized by society. They are forced to reveal hidden lifestyles to family and friends. They are also frequently rejected by loved ones and often have to face and cope with many serious losses. These learners are negatively affected because they are grieving the loss of a parent and they may be stigmatized by society because of their association with HIVIAIDS (Strode \& Grant, 2001:1). Most children have not come to terms with the reality of being orphaned and of their parents, the normal grief process is worsened by guilt that they were unable to confess to being ill equipped to provide proper parental guidance and discipline to their siblings, let alone the love and care which they themselves need. Here is also no moral and ethical guidance from these children, where the only adult attention may be in the form of uneven and insufficient supervision. Most children describe having lost their social friends due to their rigid time budgeting which does not allow them time to play.

The infected child suffers additional emotional pain due to rejection from the peer group. "It is common for a chronically ill child to think that he shouldn't have been born. These thoughts make the child feel that $\mathrm{h}$ is a burden, no 
good, not wanted a disgrace, or an untouchable. Such feelings cause low self-esteem and contribute to a sense of inadequacy. Children with low self-esteem may believe that they can't succeed in school even if they try, and they are prone to unhappy preoccupations" (Morrow, 1985:44-45).

The demands to care for a sick family member would lead to the neglect of the care givers' own needs and of those others in the household. Caregivers are also at risk from taking care of sick family members who haven't disclosed their status. A feeling of insecurity and uncertainty of the further after the mother's/father's death is depressing for the children. Children are vulnerable to abuse and neglect. This is quite often associated with the increased movement of children onto the street or into commercial sex work and the increase of child labour.

\section{Physical Impact of HIVIAIDS on Learners}

Children who are affected or infected by HIVIAIDS are vulnerable to malnutrition and under-nutrition, due both to scarcity of food and to the weak position they occupy within guardians' homes in the household resource distribution process. Elderly grandparents and children often cannot maintain their homes. Poverty within the extended family frequently results in repairs being neglected. Often, the family's supply of bedding is reduced because the deceased parent was bedridden and incontinent before death and it is common for children to sleep on sacks or cardboard boxes on the floor. Many children have no footwear at all and own only one set of clothes. Furthermore, immunization and simple medical care may not be reaching these children, and children under the age of five are particularly vulnerable (Smart et al., 2001:33).

The role of the teacher in supporting Infected and/or affected by HIVIAIDS children in the classroom

According to Louw et al. (2001:8) the teachers and the learner meet at a school (classroom) in a learning situation where the teachers aims at helping the child to learn. As teacherss are beginning to come into an ever-increasing contact with learners infected and affected by HIVIAIDS at school, the teachers must be prepared to deal with the disease in their classrooms. The teachers does not nece3ssarily know who the infected or affected learners are and because the teachers has a responsibility towards learners, a system of identification should be devised to enable the teachers to care for and support those in need (Louw et al., 2001:8).

Louw et al. (2001:11) further maintain that it is important for all teacherss to realize the responsibility of equipping themselves with the necessary skills to care for and support learners who are infected with HIVIAIDS in most effective way.

The fact that HIVIAIDS is still accompanied by stigmatization, discrimination and prejudice means that social, emotional and spiritual support is important.

As far as the affected and infected learner is concerned, the school can play a major role in this kind of support. The teachers will more than likely be one of a few trust worthy adults who can fulfill many of these needs of the learner and the family (Louw et al., 2001:13). The teacher is expected to take on the additional roles of parent, nurse, social worker, occupational therapist and psychologist. Lazarus, Daniels and Engelbrecht (1990:50) consider the challenge of schools as being: "to develop barrier-free teaching and learning environments which accommodate the diverse needs of the learning population and enable all learners to move around freely". Engelbrecht and Green (2001:40) mention that teacherss play an important role in developing an inclusive learning community as they are in a direct relationship with the learners on daily basis. The teachers should, further, promote classroom cultures that welcome, appreciate and accommodate diversity in which every learner feels valued, safe connected and cared for. In the following section the traits of a dedicated teacher will be discussed.

\section{The Role of the Teachers Regarding the Cognitive Aspect of the Learner with HIVIAIDS}

According to Louw et al. (1998:70) research has indicated that learners with chronic illness experience more academic difficulty than their healthy peers. Forty-five percent (45\%) of learners with chronic illness report falling behind in their schoolwork, which results in a dislike of school. It is therefore important if the teachers is aware of chronic illnesses and the pressures that they put on the learner and the family. This knowledge will enable the teachers to be supportive to both learners and parents, modify the school programmes and be aware of the effects of any medication which could cause alterations in behavior, such as drowsiness. Peer tutoring will also be an effective tool to assist ill learners.

Murray (1992:213) outlines that the teachers needs to be a motivator who must encourage learners to do their best, think problems through and have self-discipline. This develops independence and allows the teachers to have quality time with an individual learner without having to continually break away to direct the other learners. The teachers should also acknowledge that learners do not learn at the same rate or in the same way and should be equally aware that 
one set of goals is not appropriate for all learners. Therefore, teachers should design lessons which permit multi-level participation; for example, while other learners are reading novels, the learner with visual impairment is listening to a taped version of the novel and the other learners with lower reading vocabularies have access to a modified version or a peer reader. It is the teacher's obligation to work closely with parents and give constant feedback regarding the progress of the learner. The teachers should also seek support from the Multi-Disciplinary Team (MDT) such as psychologist, speech therapists, and specialists for children who are blind or deaf, and sometimes physiotherapists.

In the school situation, the learner who is infected or affected by HIVIAIDS will be a learner like any other learner in the mainstream education (Louw et al., 1998:75). However, it is not true that all learners who are infected by HIVIAIDS will need special support in some way. The school, as well as the Department of Education, will have to support and assist such a learner as they would assist any other learner who is encountering difficulties to learn. A teacher, but particularly the class teachers, will have to take responsibility to identify learners who have problems and refer them to School-Base Support Teams for more care and support (Louw et al., 2001:80).

The teachers should recognize barriers to learning and development which learners infected and affected by HIVIAIDS may experience and how to give them academic support. Murray (1991:212) points out that teachers should make conscious efforts to interact with each learner every day. She motivates this by encouraging teachers to ask other adults to handle the class which may be working on an assignment or tasks prepared by the teachers, while the teachers works with an individual learner. Teachers sometimes become social coordinators, creating a cooperative rather than a competitive environment by designing activities, both academic and social, which support cooperative values. The author further emphasizes that individual learners are not lost in the cooperative structures; instead they are shown that they each have something to contribute which is of equal value to everyone's contribution. The teachers role should also be to include all learners, even mentally handicapped learners in most activities and quietly encourage interaction without drawing special attention to it. The other learners soon assume responsibility for any extra needs the children might have, and this develops strong bonds within learners.

Kapp (1991:36) reports that the teachers is/in a good position to notice behavior and learning problems in learners. This is supported by the fact that the teachers can gather information that will enable him/her to reach a better understanding of the learner. The teachers evaluate and assess the child in an educational setting, which implies the identification of factors, which may interfere with the learner's development. Van Niekerk (1980:71) says that it is good when teachers realize the importance of severe learning disabilities in elementary school learners of normal intelligence and are able to do something about this problem.

\section{Research Methodology}

The topic of this research deals with a very sensitive issue, and needs in-depth investigation on teacher's role in supporting the infected and/or affected by HIVIAIDS children in the classroom. Therefore a qualitative approach to this study was followed. "Qualitative research describes and analyses people's individual and collective social actions, beliefs, thoughts, and perceptions" (McMillan \& Schumacher, 1997:395). According to Krueger (1994:24) a researcher who intends gathering information that lays emphasis on words and observations to explain reality, should make use of the qualitative method. In this study, the data to be collected is verbal in nature. To collect data I used semi- structured interview as it helped to explain in detail. For the purpose of this paper, we interviewed and observed eight teachers from eight different schools. The interviews were held during school time and lasted approximately 2-3 minutes. I conducted individual face-to-face interviews and did the observations with all the five teachers.

The focus group as qualitative research tool was used to collect data whereby a small number of respondents discussed the role of the teachers in meeting the needs of the HIV positive learner. Maykut and Morehouse (1994:71) define a group interview as a group conversation with a purpose that is a set of individual interviews that take place in a group setting. The most important quality of group interviews is using the dynamics of group interaction to gain information and insight that are less likely to be gained through individual interviews. It is conducted as open conversations in which participants may actively share ideas and ask questions or comments to questions posed by others.

\section{Recommendations}

\subsection{Education}

Education should be regarded as the most important tool against the spread of HIVIAIDS. It is important to inform 
learners about the disease so that they make decisions about their lives. Special events to make people more aware of HIVIAIDS should be made in order to educate people, for example, AIDS day. Parents and teachers should talk freely about sex in order to prevent HIVIAIDS spreading.

\subsection{Teachers and learner}

I recommend that teachers and all the support structures contribute to ensure that infected and affected learners in schools are cared for and supported according to their specific needs. Furthermore, teachers should counsel learners who need assistance with social or learning problems and treat the learners with HIVIAIDS in a just, humane and lifeaffirming way.

Teachers needs to be watchful of any hurtful attitudes and behaviours in schools, take action to defuse any situations that might occur, deal effectively with the guilty ones and ensure the well-being of all learners and especially the learners in need (Government Gazette, 1999:14-20).

\subsection{School and learners}

DECS (1997:165) argues that schools should teach everybody that is, teachers, learners, parents and people who are working in the schools the correct methods of how to clean u accidental blood and body fluid spills. Schools should develop standard procedures that have to be applied in all activities in which people may be exposed to blood and body fluids.

The schools should ensure that appropriate protective equipment is always readily available for dealing with spilt blood and body fluids and that staff are trained to institute safety. Appropriate first-aid equipment should also always be readily available for dealing with spilt blood and body fluids. Re-education and training to parents and community members about safety measures should be provided by developing proactive policies, for example, developing the following first-aid procedures. Ensuring the availability of latex gloves, providing a plastic bag in a disposal unit for bloodstained linen and first-aid education for learners to teach them how to handle their own spills, such as physical education blood spills.

Everybody should be made aware that if any person has contact with blood or body fluids, they should wash the area thoroughly with soap and water. In addition guidelines relevant to the transmission of HIVIAIDS should be available to all classes and first-aid training should be provided for staff.

\subsection{School and society}

DECS (1997:66) points out that the school should provide relevant and up to date information to all community members by using appropriate existing structures to inform and maintain awareness and relevance of HIVIAIDS education, for example, news-letters, parent groups and volunteers.

The school should encourage parental participation and involvement, conduct a needs analysis of parents and invite parents to attend curriculum committees, staff meetings and sexuality and HIVIAIDS workshops. Furthermore, the school should plan a continuous development - not a 'once-off' - by establishing parent advisory group to look at the curriculum on health and physical education issues.

The schools should also use drama presentations on the broader theme of health issues which includes sexuality and HIVIAIDS education and involve parents and community members. Local media should be used with discretion, for example, AIDS awareness or world AIDS days.

\section{References}

Department of Education and Children Services (DECS). 1997. Sexuality and HIVIAIDS Education. Australia: Cataloguing-in-Publication Data.

Engelbrecht, P. \& G. Green, L. (Eds) 2001. Promoting learner development preventing and working with barriers to learning. Goodwood, Western Cape: Van Schaik Publishers.

Hamilton, A. 2002. An article in Fairlady magazine.

Hoffman, M. 1996. Counseling clients with HIV disease. United States of America: Library of congress Cataloguing-in-Publication Data. Hubley, J. 1995. The AIDS handbook. $2^{\text {nd }}$ edition. London and Oxford: MacMillan.

Kapp, J.A. (Ed) 1991. Children with problems. Pretoria: Serva Publishers.

Kaufmann, T. 1995. HIV \& AIDS and older People. Great Britain: Age Concern England. 
Krueger, R. A. Focus groups: a practical guide for applied research. Thousand Oaks, CA: Sage Publications Mann, J. Tarantola, D.J.M Relume - Damara/ Abia/ IMS - UER. \& Netter, T.W. (Eds) 1992.A Aids No Mundo, Rio de Janeiro:

Maykut, P. \& Morehouse, R. 1994. Beginning of qualitative research. A philosophical and practical guide. London: The Falmer Press.

Morrow, G. 1985. Helping chronically ill children in school: A practical guide for teachers, counsellors and administrators. New York: Harper Collins.

Murray, M. 1991. The role of classroom teacher. In: Porter, G.I. \& Richter, D. Changing Canadian schools. Perspective on disability and inclusion. New York: Rocher Institute.

Smart, R. Dennil, K. \& Pleaner, M. 2001. A primary HIV/AIDS capacity development course for government planners. Pretoria: Department of Social Development.

Strode, A. \& Grant, K.B. 2001. Children, HIVIAIDS and the Law. South Africa: Save the Children. (UK)

Van Greunen, A. 2001. Wie gaan na die kinders kyk? De Kat, April 2001. Volume 16, No 10.

Van Niekerk, P.A. 1980. Orthopedagogiese navorsing: 'n Inleidende oriëntering. In: landman, W.A. (red), Inleiding tot die opvoedkundige navorsing praktyk. Pretoria: Butterworth.

Whiteside, A. (Ed) 1998. Implication of AIDS for Demography \& Policy in Southern Africa. South Africa: Creda Communications.

Whiteside, L. \& Sunter, C. 2000. AIDS the challenge for South Africa. South Africa: Tafelberg Publishers Ltd. 